\title{
A proposal for prospective late outcome analysis of decellularized aortic valves
}

\author{
Ko Bando, MD, $\mathrm{PhD}$
}

From the Department of Cardiac Surgery, The Jikei University School of Medicine, Tokyo, Japan.

Disclosures: Author has nothing to disclose with regard to commercial support.

Received for publication April 26, 2016; accepted for publication April 28, 2016; available ahead of print June 4, 2016.

Address for reprints: Ko Bando, MD, PhD, 3-28-5, Nishi Shinbashi, Minato-ku, Tokyo 105-8461, Japan (E-mail: kobando@jikei.ac.jp).

J Thorac Cardiovasc Surg 2016;152:1202-3

$0022-5223 / \$ 36.00$

Copyright (c) 2016 by The American Association for Thoracic Surgery

http://dx.doi.org/10.1016/j.jtevs.2016.04.087

Although cryopreserved aortic valve allografts (CAVAs) have been used for more than 50 years with excellent long-term results in older patients, durability is limited in younger patients, especially in those younger than 20 years. The mechanisms responsible for calcification and structural tissue degeneration are multifactorial and not fully understood. It is widely accepted that aortic valve allografts cause low-grade immune reactions in the host; however, the correlation between the severity of this reaction and late graft dysfunction has not been sufficiently clarified. Decellularization has been postulated as a promising technique for processing biologic tissues. ${ }^{1}$ Theoretically, the complete removal of cells and cellular debris results in a nonantigenic scaffold, which is capable of being repopulated in vivo after implantation; thus this remodeled "patient's own valve" may provide enhanced durability and be less prone to degeneration and calcification. ${ }^{2}$

Indeed, decellularized aortic valve allografts (DAVAs) have demonstrated satisfactory initial results. The Mayo Clinic demonstrated that minimal inflammation and localized microscopic and dystrophic calcification were observed in the explanted SynerGraft (CryoLife Life Restoring Technologies, Kennesaw, Ga) 2 years after surgery. ${ }^{3,4}$ Da Costa and colleagues ${ }^{5}$ indicated that DAVAs provided stable structural integrity, a low rate of calcification, and adequate hemodynamics as late as 4 years after surgery.

In this issue of the Journal, the report of Helder and colleagues $^{6}$ from 2 institutions that have had considerable experience with aortic root replacement with a SynerGraft have now raised a "caution flag" after a 10-year followup. Although freedom from reoperation at 5 postoperative years was similar between the DAVA and the conventional CAVA groups, freedom from reoperation at 10 postoperative years was substantially lower in the DAVA group $(51 \%)$ than in the CAVA group $(80 \%)$. Of note, the explanted valves with sufficient tissue for analysis demonstrated edematous degeneration and calcification of the valve in the majority of cases (7/10) and adventitial

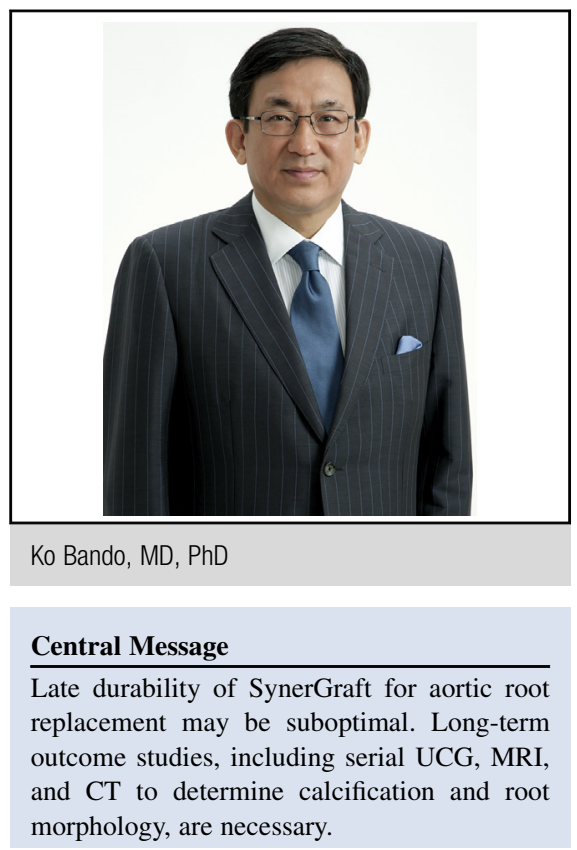

See Articles page 1156 and 1197.

See Editorial Commentaries page 1165 and 1200 .

fibrosis and neointimal fibroplasia in all cases, whereas only mild recellularization was present in only $30 \%$ (3/10) of the cases. Fibrosis and calcification have been reported to be typical types of failure for CAVA, and this important but brief research report ${ }^{6}$ indicates that modes of failure were similar between the 2 groups.

Decellularized allografts may perform well in the right side of the heart, ${ }^{7,8}$ whereas there were solid concerns that complications such as aneurysmal conduit dilatation or valvular cusp prolapse might occur when decellularized tissues were exposed to the higher pressures of systemic circulation. In fact, several reports indicated that the SynerGraft decellularized pulmonary homograft demonstrated an equivalent or better performance than did standard cryopreserved valve allografts as late as 9 years after surgery. ${ }^{7,8}$ Unfortunately, a 10-year followup is not yet available. I would propose a late outcome study to determine whether this theoretically attractive SynerGraft offers true advantages relative to conventional allografts. Such an outcome study should be conducted in a prospective fashion that includes serial echocardiography, 
computed tomographic scan with the calcium score measurement, and magnetic resonance imaging to determine the annulus and sinus as well as the sinotubular junction diameter in both the systolic and diastolic phases. ${ }^{5}$ I applaud Helder and colleagues ${ }^{6}$ for their honest and timely reporting, which has been a longstanding tradition of their 2 distinguished institutions. At the same time, this important "word of caution" should certainly encourage other surgeons who have been involved in implantation of decellularized SynerGraft valves to report their own late postoperative experiences.

\section{References}

1. O'Brien MF, Goldstein S, Walsh S, Black KS, Elkins R, Clarke D. The SynerGraft valve: a new acellular (nonglutaraldehyde-fixed) tissue heart valve for autologous recellularization. First experimental studies before clinical implantation. Semin Thorac Cardiovasc Surg. 1999;11(4 Suppl 1):194-200.
2. Cebotari S, Mertsching H, Kallenbach K, Kostin S, Repin O, Bartrinac A, et al Construction of autologous human heart valves based on an acellular allograft matrix. Circulation. 2002;106(12 Suppl 1):I63-8.

3. Zehr KJ, Yagubyan M, Connolly HM, Nelson SM, Schaff HV. Aortic root replacement with a novel decellularized cryopreserved aortic homograft: postoperative immunoreactivity and early results. J Thorac Cardiovasc Surg. 2005; 130:1010-5.

4. Miller DV, Edwards WD, Zehr KJ. Endothelial and smooth muscle cel populations in a decellularized cryopreserved aortic homograft (SynerGraft) 2 years after implantation. J Thorac Cardiovasc Surg. 2006;132:175-6.

5. da Costa FD, Costa AC, Prestes R, Domanski AC, Balbi EM, Ferreira AD, et al The early and midterm function of decellularized aortic valve allografts. Ann Thorac Surg. 2010;90:1854-60.

6. Helder MR, Kouchoukos NT, Zehr K, Dearani JA, Maleszewski JJ, Leduc C, et al Late durability of decellularized allografts for aortic valve replacement: a word of caution. J Thorac Cardiovasc Surg. 2016;152:1197-9.

7. Brown JW, Ruzmetov M, Eltayeb O, Rodefeld MD, Turrentine MW. Performance of SynerGraft decellularized pulmonary homograft in patients undergoing a Ross procedure. Ann Thorac Surg. 2011;91:416-22; discussion 422-3.

8. Ruzmetov M, Shah JJ, Geis DM, Fortuna RS. Decellularized versus standard cryopreserved valve allografts for right ventricular outflow tract reconstruction: a single-institutional comparison. J Thorac Cardiovasc Surg. 2012;143:543-9. 